\title{
The Factors Influencing Quality Work Culture in Education in Indonesia: A Case Study at Graduate Program of Educational Management, Universitas Lambung Mangkurat
}

\author{
Ahmad Suriansyah \\ Graduate Program of Educational Management \\ Universitas Lambung Mangkurat \\ Banjarmasin, Indonesia \\ a.suriansyah@ulm.ac.id
}

\begin{abstract}
The objective of the study is to identify the factors influencing quality work culture in education in Indonesia. This study focuses on teachers who study in a graduate program of educational management. It was particularly because the teachers who are students in the graduate program will back to schools after graduating. Determining their quality is important so that they will be good agents for growing quality culture at schools, which will further impart their quality into the students to drive the organizations in the nation for the future. A case study approach was utilized to study deeply on the matter. Qualitative techniques such as observation, interview, and document study were utilized for collecting data from $\mathbf{3 0}$ master students that involved in this study. In the end, it was found that leadership, educational management, human resources management, information management, customer satisfaction focus, and partnership management are an important factor that influences the quality work culture.
\end{abstract}

Keywords—quality; work; culture; schools

\section{INTRODUCTION}

Reference [1] urges that knowledge expansion and technology evolvement is swift, sophisticated and never ends; they influence all humankind systems. So, educational institutions in which they contain the similar system inside are unable to skip from those effects of developments. As a result, each educational institution is expected to predict various possible change and fulfill the needs of quality management with these characteristics: (1) move more actively on its mission, (2) supports customer needs, (3) be proactive, (4) be competent, (5) the man power is more hardworking, (6) the man power continuously make efforts, (7) the leaders committed in empowering the personnel, (8) the leaders encourage personnel to upgrade their knowledge and effectiveness suitable with the nature of works, and (9) its planning is holistic and its implementation is at the lowest level [2].

Educational institutions with the above-stated characteristics are expected to create innovations and management transformation for the organization. However, Indonesian rate in Asian education (including Australia) in 2017 was rather low at the ninth. Japan, Hong Kong, Singapore, Australia, China, and Taiwan were rated at the first sixth chronologically and also the indicator of the quality of education can be seed in Human Development Index (HDI) Indonesia. As an example, in 2017 Indonesia was at the 116th of 189 countries but improved drastically to be at 105 in 1999 . This figure contradicts with the suggestion that one of the main missions of education worldwide is its quality of products [3]. So, in this global era, HLI that are not professionally managed and not maintain their quality will lose in various competes. They will not be able to make their people sustain in the global markets.

The Higher Education General directors emphasize that Indonesian education system management focuses on implementing continuous quality. This requires effective quality management implementation because organizations which implement continuous quality management can sustain in the global market [4]. This is partly because, in the implementation of quality management, organizations are closely related to customer behavior [5]. These show that organizations should adapt competition-oriented, continuous improvement, high quality management system. Reference [4] addresses that quality includes "leadership and quality culture, continuous improvement and innovation in the educational process, employee participation and development, fast response and management of information, customer driven quality and partnership development" to be practiced.

Although many have realized the importance of quality management and its effects on the products and customers, HLI management in Indonesia is weak [6]. Among the problems include: (1) uncertain bureaucracy that delays works; (2) low quality of humankind works; (3) work redundancy; (4) high leakage; (5) need of tight control; (6) limited locus of work freedom; (7) difficult to manage manpower; (8) unsatisfied output; (9) low ability to compete; and (10) feudalistic work culture. These make the HLI slow and limit the abilities to 
innovate. Consequently, the HLI graduates are not able to compete in the global market.

When the above-stated weaknesses are examined, it can be observed that the weaknesses of HLI fall at its work culture, organizational culture or individual and group culture in the organization which is still not appreciating quality culture as a work culture [7]. This points out a serious question, why does this happen? In fact, the HLI has been developed a long time ago and is set as a community development agent.

Based on this premise, HLI (including Teachers Trainee College/Graduate Program of Educational ManagementGPEM) whose their graduates will serve other institutions (in this case is GPEM) should implement TQM so that customers can satisfy with their graduates. However, the question is whether the HLI especially the GPEM implements TQM in their operations? This arises because if the quality of GPEM is low, the qualities of their graduates who serve at primary schools are also low. Therefore, the primary school leavers will enter the higher levels of schools until the HLI with insufficient quality. This is very important because what is gained at the primary level will be inherited to the higher levels. In relation, reference [8] have argued that in the context of national education, the primary school must be given priority. Everyone agrees that one cannot proceed to secondary school and later the HLI without doing the primary school. Reference [9] states at least two functions of education at primary schools. First, the students will be able to absorb basic abilities in thinking critically and imagining through reading and writing [10]. Second, it prepares students with foundational knowledge to proceed with education at higher levels.

According to them, the primary education is the most basic to all higher levels. They added that how students perform at the primary level determines how they will do at the secondary level as well as at HLI [10][11]. Fuad Hasan and Sarwono Kusumaatmadja, the previous Minister of Education and Culture and Minister of State for Administrative Reform period 1988 to 1993 year, state that the importance of education at primary level has been realized by countries worldwide by increasing their investments for the primary education, as seen in Arab Countries, Africa, Latin America, Japan, and Thailand [12].

Because of its importance, the primary education should be seriously moulded in terms of its infrastructure and contents, in its process and outputs so that everything is of good quality. In terms of institutional management, the schools should be managed well so that it outputs school leavers who are socially and mentally matured. In the matter of academics, all elements at the primary schools including the manpower, curriculum, and other educational elements should be upgraded to meet and expand the mission [13]. This shows that the quality of primary schools must be good. To achieve that, their teachers' quality must be good. This means that GPEM as the institution that trains teachers must be able to produce good quality teachers, teachers who are competent.

Most of the competency indicators can be measured from activities and teachers at school and in classrooms. Can teachers do teaching preparations well? Do teachers teach using suitable techniques and methods? Do teachers utilize media and teaching aids effectively? Do teachers assess students work correctly? These questions indicate whether teachers are competent, through their activities at school and in classrooms. In short, the school and classrooms record teachers' activities (referred to as the black box) in teaching and learning.

In upgrading teachers' competency, efforts should be taken at the pre-service education in teachers trainee colleges. This means that district officers should play roles. In addition, educational and training institutions are also responsible for training teachers so that everything is in line with the latest climate in national education including educational theories and concepts. Co-operations among the three institutions which covers pre-service, in-service, and on-the-job training is compulsory, to upgrade teachers' competency in making teaching and learning process more effective.

Based on the above-discussed points, it is important to improve the quality of programs for teacher education to produce quality primary school teachers. Without improvement at teacher education level, the quality of education at primary level will be affected, hence will affect up to the HLI level.

The need for improvement of teacher education is more desired when reflected in the real situation, where teachers at primary schools are less able to compete. According to a study by National Education Development and Study Body (Balitbang-Diknas) in 1999-200, there were 608,032 not qualified teachers out of $1,054,859$. This means $57.6 \%$ teachers were actually not qualified to teach at the primary schools [14]. Similarly with South Kalimantan in which the quality of primary school leavers was below five for Nilai Ebtanas Murni. This is because of the low quality and competency of teachers, which has been proven through competency, test among the teachers where their competency levels were found between $50 \%$ and $60 \%$ [15].

Besides the demand for quality among primary schools, quantity is also in demand in South Kalimantan. In 2004, the demand for primary school teachers in South Kalimantan was more than 5,000 [16]. Accordingly, institutions for primary teacher education should upgrade their institutions so that they can produce quality and professional teachers. This is important so that they can serve well when teaching.

As discussed in the previous paragraph, it is an urgent need to study problems and boundaries for implementing quality management at primary level, as resolutions and guidelines in nurturing education for the future. This type of study is important because current studies on education quality are more towards the 'functional production' theory that only suggests input factors in the education process that determines the quality of education outcomes [17]. That type of study, which are based on the 'functional production' theory, do not relate with the black box in the education process, where all inputs are organized not only at education level but also at the policy level. This has been argued by reference [17] who stated education is not just about knowledge but also about management and application. 
Reference [17] further stated that studying the black box in the education process is not just by the survey, either longitudinal or cross-sectional, but it requires case studies that consider success and failure at the institutional level and understand their vision and mission in respected context. From the cases, generic lessons could be obtained to upgrade quality. Works in improving quality through money and input quantity will not ensure the quality output as desired [18]. It means that improving quality requires non-conventional methods and at the same time continuing the conventional efforts. In short reference [18] suggests improving the work culture to improve the quality of education.

Based on the above-discussed arguments, this study inspects the quality work culture with qualitative approach and case study so that 'what' and 'how' the actual black box of the education process in teacher training colleges happens can be clearly explained. Educationists have made suggestions, and Dasar Pendidikan Indonesia has been introduced, but the quality of education in Indonesia is still low [1], [3]. Also, many people have realized the importance of TQM in producing a quality product, but its implementation in education in Indonesia is still weak [6].

In addition, although studies found that organizations implementing corporate work culture can produce outstanding outputs with good quality [19]; the practice of work culture in HLI is non-identifiable [20]. When the root of weaknesses is examined, it was found that the weaknesses of HLI are at its work culture, organizational culture or individual and group culture in the organization which are still not appreciating quality culture as a work culture, and the existing is the culture of waiting for jobs and not creative [7]

To solve the problems as discussed in previous paragraphs, this study aims at identifying factors influencing quality work culture in teacher trainee colleges. The quality aspects are referred to for summarizing the results [4]. As mentioned earlier, a case study is utilized. Hence, GPEM ULM Banjarmasin is scoped for the study.

This section addresses some problems regarding quality culture in primary education in Indonesia with background knowledge of education in Indonesia and quality management. The aim of the paper is also stated at the end. Then, the methods to achieve the aims are discussed in the next section, followed with a section discussing the results obtained from the activities. Next, the results are discussed in the following section with some recommendations for future works.

\section{METHOD}

A good methodology should bring the researcher to achieve the objective of research [21-23]. This study utilizes a qualitative approach, using words, concept, and information without numbers or algebra symbols [24]. The researcher involved completely in observation and interview to characteristics of qualitative that are (1) natural setting, (2) descriptive, where descriptions are referred to exact period, (3) focus on process, not the product, and (4) data tend to analyze inductively [25].
The purposive sampling is utilized, in which the main informer was identified to deeply study the case in the focus of study through snowball sampling to 30 master student of educational management program as respondents that involved during data collection. The respondents were interviewed on their experience and involvement, knowledge, and opinions regarding the profile and history of graduate program of educational management, programmed vision including vision and mission, lecturer's recruitment, entry requirement, target students, leadership, educational management, human resource management, information management, customer satisfaction focus, and partnership management. All data were recorded in qualitative forms in writing, and audio taped.

The gathered data were analyzed using domain, taxonomy, component, and theme techniques, which are recommended by reference [26]. Domain analysis was used to address the problems regarding the implementation of TQM in GPEM ULM Banjarmasin in general. While creating a taxonomy for the sequences of problems regarding the implementation of TQM in GPEM ULM Banjarmasin was using the taxonomy analysis. Further, the component analysis was utilized in systematically identifying attributes and elements regarding the problems. It involves searching, reduction, grouping, and clustering into dimensions. Finally, the theme analysis was used to identify themes during the study. Internal and external themes regarding the TQM in GPEM ULM Banjarmasin were both identified.

\section{RESULTS AND DISCUSSION}

Having collected the data through various qualitative techniques as elaborated in the previous section, this study deduces that the following are factors influencing quality culture in teachers' trainee colleges:

- Individual and group culture inherited into an organization will influence the organization and form a new culture. The stronger the culture, the longer it takes to form a new culture. Hence, the quality culture is influenced by individual culture, in which the individual culture could be integrated into organizational culture with appropriate strategies. The creation of culture is influenced by continuous improvement works, intensive socialization of the organizational expectation, reward system, and monitoring.

- The formation of quality work culture with quality, values, and work culture standard formulation, which is understood by all members. The understanding should start with socialization, involvement at various levels, and monitoring. Involvement of all members in formulating basis creates the sense of ownership and responsibility as well as accountability among GPEM ULM members.

- Forming quality culture is not just by the commitment of leaders only. It needs the commitment of all staffs, academic and non-academic. Further, to from the commitment of all staffs, socialization alone is not enough. It requires leaders to show their practices. 
Also, supports of staffs' needs in terms of material and spirit are important.

- Staffs' competency improvement should be of focus by GPEM ULM Banjarmasin in supports of customer services quality. The improvement should be wellplanned, based on lecturers' needs (competency-based training). This means the training should be organized whenever competencies are found weak and need to be improved.

- The strong commitment of a lecturer in improving teaching quality and making students active is an important factor in forming quality learning culture among students. This means the quality culture should start with a role model which is the lecturer. On the other hand, the formation of lecturers' competency is done in a well-planned manner based on needs.

- Innovative product culture among lecturers is influenced by the ability and writing culture which is supported by the institution. Without the ability and writing culture as well as the support of the institution, the innovative and productive culture will not be developed. This means that the formation of innovative and productive work culture will work from awareness and commitment. It should be supported by supports of the institutions.

- Autonomy in aspects including development of learning facilities and infrastructure and studentship and human resources should be supported with clear job specification. Besides, it needs smart coordination for the creation of quality culture because the autonomy and coordination are important elements of TQM implementation.

- The incentive for job accuracy strongly contributes to quality work culture, especially the accuracy and correctness of the services to students. However, incentive alone is not enough to create and develop the quality work culture without healthy working climate. The healthy working climate could be formed through clear and easy communication styles such as informal and more as a family.

- Works in satisfying customers are very important in managing GPEM ULM Banjarmasin to develop quality. It could be initiated through (1) identifying customer satisfaction through questionnaire and other informal techniques with students, (2) organizing workshops involving district education office, supervisor, headmaster, teachers, and alumni with lecturers and university leaders to formulate graduate's competency and curricular, (3) asses and monitor graduates' competency periodically and continuously, and (4) it will improve customer satisfaction.

- Partnership with various parties is always based on customer satisfaction as the main aim. To support customer satisfaction, the human resources in the partnership should be selected on certain competency criteria. It means that customer satisfaction must be guaranteed and commitment towards quality should be ensured in the partnership.

Referring to the results in the previous section, factors of quality work culture found in this study include standard operational procedure which is supported by official letters. This means quality work culture will accelerate with a clear system. Besides, leader's commitment towards quality, unite perceptions, staffs' commitment towards quality, planned and continuous competency improvement activity management autonomy, collaboration and partnership with external stakeholders, trust on transparent, responsible, collaborative, and loyal management, incentive and rewards, monitoring, and periodical and continuous assessment are also important in forming quality work culture. Based on the analyzed data, the quality work culture can be classified as listed in Table I.

TABLE I. ClassificATION OF QUALITY WORK CULTURE

1. Leadership

1.1 High leadership, collaborative, and collective.

1.2 The purposes are clarified in various ways and exhibited to everyone.

1.3 The institution clarifies the long-term expectations in detail.

1.4 The system is organized following standards and guidelines.

2. Educational management

2.1 The design process involves all members of the institution.

2.2 Delivery is made through various ways including ICT.

2.3 Innovative design is provided with incentive and rewards.

2.4 Effective management is done with ethics, recognition, and punishment.

3. Human resources management

3.1 Competency improvement training is done through workshop, seminar, and learning tasks.

3.2 A conducive climate with the participative approach.

3.3 Encouragement is granted through rewards, incentive, and publicity.

4. Information management

4.1 ICT is used effectively to socialize various bases for further actions.

4.2 Information is obtained from various reliable sources.

4.3 Information is the basis for the making of bases and guidelines.

5. Customer satisfaction focus

5.1 Identifying customer needs is done by involving all parties.

5.2 Understand customer needs, involve customers in planning, assessing, and monitoring.

6. Partnership management

6.1 All stakeholders are discussed with (head master, supervisor, Dinas Pendidikan).

6.2 All parties at the Graduate Program of Educational Management are involved actively.

Table I explains that leadership, educational management, human resources management, information management, customer satisfaction focus, and partnership management are important in ensuring quality work culture in teachers' trainee college. The implications are big to the education in Indonesia. As mentioned earlier, the quality of education origins from the teachers. Hence, ensuring quality culture in the college can help teachers to have enough quality when they teach in schools. Further, the students in the school are anticipated to gain quality education from the teacher.

The findings in this study are almost similar with reference [27], who found aspects including training, customer focus, 
members' involvement, top management commitment, quality organization, strategic planning process, and information analysis are important factors. In addition, earlier research in different places such as reference [2], [28-31]. This shows that the factors remain important on a time spectrum. In fact, Ciampa addressed in 1991 that the culture change could be made through a continuous program on quality [32]. On the other hand, studies in America and England by reference [3334] about quality improvement produce models. The model contains variables like this study. Among the similarities include the facts about quality planning (culture standard, vision, mission, purposes, characteristics and values from the beginning). Meanwhile, at Penn State University, the vision, mission, and major (in this study is referred to as the Graduate Program of Educational Management culture) are some elements in leadership factor and strategic planning.

In relation, strategic planning in this study is part of the organization management process. The findings in this study confirm that quality culture in organizations will not be formed without a process. The processes should be started from the beginning, with a basis as the guidance for actions among the members. It is in line with reference [35] who clarify that TQM is a consistent management system towards the root of a quality value, technique, and tool. The root of quality is the basis of quality work culture [36]. That is why the quality work culture should start by identifying the root of quality value and select techniques and strategies that strongly support values and finally apply the support tool correctly. Reference [37] mentions that organizations which implement TQM have changed their culture. The quality culture has been absorbed with elements such as team work, customer focus, and involvement of staffs and management. This means that quality work culture could be formed when TQM is integrated into the organizational culture and individual culture.

Also, according to reference [38], the work culture leads to togetherness. Hence reference [39] mentions that togetherness is formed by the members of the organization so that the organization is special than the others. It means the togetherness is a special element that makes a difference. This is because the work culture is the nucleus in the relationships among staffs. Later, this has also been firmly mentioned by reference [19]. Besides, reference [40] mention that work culture as a value system, confidence, in an organization that interacts with formal structure could form some norms. The knowledge and understanding then become the strategy for being excellent. This is supported by findings of reference [41] that knowledge should be expanded in the implementation of innovative, systematic, holistic management. This means that the organization should start with changing work culture towards quality culture.

\section{CONCLUSION}

As discussed at length in the previous section this study has identified factors influencing the quality work culture in teachers' trainee colleges in Indonesia. The findings are in line with factors influencing quality work culture in other places. The factors are important for consideration to ensure the students of teachers' trainee colleges are competent in terms of their quality. When they are competent, with good quality, they could be good and competent teachers when they teach in schools. Hence, they will give benefits to their students in primary schools. In the long term, these students (in the primary schools) will contribute to the nation. With competent teachers who they were taught by, it is expected that the new generation will inherit good quality from their teachers. Then, they manage the organizations in the country well.

\section{REFERENCES}

[1] I. Bafadal, Supervisi Pengajaran Untuk Meningkatkan Mutu Pendidikan. Malang: IKIP Malang, 2000.

[2] G. K. Kanji and H. Yui, "Total Quality Culture, Total Quality Management," vol. 8, no. 6, pp. 417-428, 1997.

[3] H. A. . Tilaar, Sistem Pendidikan Nasional Yang Kondusif Bagi Pembangunan Masyarakat Modern Berdasarkan Pancasila. Jakarta: LIPI, 1991.

[4] S. Venkatraman, "A Framework for Implementing TQM in Higher Education Programs," J. Qual. Assur. Educ., vol. 15, no. 1, 2007.

[5] V. A. M. Glinow and M. L.S., Organizational Behavior, 4th ed. New York USA: McGraw Hill International, 2007.

[6] M. F. Gaffar, "Profesionalisme Manajemen Perguruan Tinggi Pada Era Globalisasi," in Makalah Seminar Internasional, tanggal 29-31 Agustus 2004 di Jakarta, 2004.

[7] B. Sujanto, Manajemen Pendidikan Berbasis Sekolah. Jakarta: Sagung Seto, 2008.

[8] D. D. Wilson and D. A. Collier, "An Empirical Investigation of the Malcolm Baldrige National Quality Award Causal Model," Decis. Sci., vol. 31, no. 2, pp. 361-390, 2000.

[9] Departemen Pendidikan Nasional, Peraturan Pemerintah Republik Indonesia Nomor: 19 Tahun 2005 Tentang Standar Nasional Pendidikan. Jakarta: Depdiknas RI, 2005.

[10] T. R. Joni, Cara Belajar Siswa Aktif, Wawasan Kependidikan dan Pembaharuan Pendidikan Guru. Malang: IKIP Malang, 1983.

[11] E. Stoops and R. E. Johnson, Elementary School Administration. New York: McGraw-Hill, 1967.

[12] Dirjen Pendidikan Tinggi, Praktek Baik Penjaminan Mutu Pendidikan Tinggi. Jakarta: Dirjen Dikti Depdiknas, 2005.

[13] D. A. Amidjaja and Tisna, Pola Pembaharuan Sistem Pendidikan Tenaga Kependidikan di Indonesia. Jakarta: Dirjen Dikti. Depdikbud RI, 1989.

[14] Mastuhu, Memberdayakan Sistem Pendidikan Pesantren. Jakarta: Logos, 1999.

[15] Dinas Pendidikan Provinsi Kalimantan Selatan, Potret Permasahalan Pendidikan di Provinsi Kalimantan Selatan. Banjarmasin, 2007.

[16] Dinas Pendidikan Kalimantan Selatan, Kalimantan Selatan Dalam Angka. Banjarmasin, 2007.

[17] M. A. Nurhadi, "Naskah sambutan Ketua ISMaPI Pusat," in Seminar international menggali manajemen pendidikan yang efektif Tanggal 2931 Agustus 2004 di Hotel Cempaka Jakarta, 2004.

[18] Zamroni, Paradigma Pendidikan Masa Depan. Yogyakarta: Bigraf Publishing, 2003.

[19] D. Moeljono, Budaya Korporat dan Keunggulan Korporasi. Jakarta: PT Elex Media Komputindo, 2003.

[20] W. Mantja, Profesionalisme Tenaga Kependidikan: Manajemen Pendidikan dan Supervise Pengajaran. Malang: Elang Mas, 2008.

[21] J. Dalle, S. Hadi, Baharuddin, and N. Hayati, "The Development of Interactive Multimedia Learning Pyramid and Prism for Junior High School Using Macromedia Authorware," Turkish Online J. Educ. Technol., pp. 714-722, 2017.

[22] J. Dalle, "Interactive Courseware for Supporting Learners Competency in Practical Skills," Turkish Online J. Educ. Technol., vol. 16, no. 3, pp. 88-99, 2017.

[23] Derlina, J. Dalle, S. Hadi, A. Abdul Mutalib, and C. Sumantri, "Signaling Principles in Interactive Learning Media Through Expert's 
Walkthrough,” Turkish Online J. Distance Educ., vol. 19, no. 4, pp. $147-162,2018$.

[24] J. Brannen, Memadu Metode Penelitian Kualitatif \& Kuantitatif. Yogyakarta: Pustaka Pelajar, 1997.

[25] A. Furchan, Pengantar Penelitian Dalam Pendidikan. Surabaya: Usaha Nasional, 1982.

[26] J. P. Spradley, Participant Observation. New York, London and Sydney: Holt, Rinehart and Wiston, 1980.

[27] M. Cruickshank, "TQM in the Higher Education Sector: A literature Review from an International and Australian Perspective," TQM Bus. Excell., vol. 14, no. 10, pp. 1159-1167, 2003.

[28] D. Adebanjo and D. Kehoe, "An Investigation of Quality Culture Development in UK Industry,” Int. J. Oper. Prod. Manag., vol. 19, no. 7, 1999.

[29] K. A. P. Ahmed, A. Y. Loh, and Zairi., "Cultures for Continuous Improvement and Learning,” Total Qual. Manag., vol. 10, 1999.

[30] J. E. Manley, "Symbol, Ritual a Dovtrine: the Culture Tol Kit of TQM," J. Qual., vol. 3, no. 2, pp. 175-191, 1998.

[31] W. Vermeulen, "Cultural Change: Crucial for the Implementation of TQM," Train. Qual., vol. 5, no. 1, pp. 40-45, 1977.

[32] D. Ciampa, "Total Quality," Reading, 1991.
[33] M. Owlia and E. M. Aspinwall, "TQM in Higher Education- a Review," Int. J. Qual. Reliab. Manag., vol. 14, no. 5, pp. 527-543, 1997.

[34] M. Zairi, A. Francis, H. Ahmad, N. A. Ali, and K. Bomtaia, "TQM Implementation-Putting Theory into Practice Example of Best Practices in Higher Education Institutions," E-TQM Journals, vol. 1, no. 1, pp. 140, 2007.

[35] U. Helsten and D. Klefsjo, "TQM As A Management System Consisting of Values, Techniques and Tools," TQM Mag., vol. 12, no. 4, pp. $238-$ $244,2000$.

[36] A. Wilkinson and B. G. Dale, "Integrated Management System: a Model Based on a Total Quality Approach,” Manag. Serv. Qual., vol. 11, no. 5, pp. 318-330, 2001.

[37] M. B. Sirvanci, "TQM Implementation, Critical Issue for TQM Implementation in Higher Education," TQM Mag., vol. 16, no. 6, pp. 382-386, 2004.

[38] E. H. Schein, Organizational Culture and Leadership. San Francisco: Jossey-Bass A Wiley Company, 1997.

[39] S. P. Robbins, Organiztion Behavior: Concept, Controversies and Aplications. London: Printice Hall International, Inc, 2001.

[40] R. W. Mondy and R. M. Noe, Human Resource Management. Massachusetts: Allyn \& Bacon, 1993.

[41] I. S. Djati, Menuju Masyarakat Belajar. Jakarta: Radar Jaya Offset dan Paramadina, 2003. 